\title{
İstanbul İlinde Kontrol Görevlilerinin Sosyo-Ekonomik Yapısı ve Sorunlarının Belirlenmesi
}

\author{
Faruk Adıgüzel $^{1 *}$, Nuray Kızılaslan ${ }^{2}$ \\ ${ }^{1} \dot{I} l c ̧ e$ Glda, Tarım ve Hayvancılık Müdürlüğü, 34295 Küçükçekmece/İstanbul, Türkiye \\ ${ }^{2}$ Gaziosmanpaşa Üniversitesi, Ziraat Fakültesi, Tarım Ekonomisi Bölümü, 60240 Tokat, Türkiye
}

M A K A L E B İ L G İ S İ

Geliş 16 Mart 2016

Kabul 07 Kasım 2016

Çevrimiçi baskı, ISSN: 2148-127X

\section{Anahtar Kelimeler:}

Kontrol görevlileri

5996 sayılı kanun

Khi-kare testi

İstanbul İli

*Sorumlu Yazar:

E-mail: farukadiguzel13@hotmail.com

\section{Ö Z E T}

Bu çalıșmanın amacı, İstanbul ilindeki kontrol görevlilerinin sosyo-ekonomik özelliklerinin ve sorunlarının belirlenmesidir. Veriler, gayeli olarak seçilen ildeki 99 adet kontrol görevlisinden Ağustos-Ekim 2015 döneminde anket yöntemi ile elde edilmiștir. Metot olarak, kontrol görevlilerinin kişisel ve mesleki özellikleri, kanunlar hakkındaki düşünceleri ve kategorize edilen sorunları için frekans, yüzde dağılım ve ortalamalar kullanılmıştır. Ayrıca, resmi kontrolleri yeterli ve etkin bulma durumu ile kontrol görevlilerinin bazı özellikleri arasındaki ilişki Khi-kare $\left(X^{2}\right)$ testi ile analiz edilmiştir. Kontrol görevlilerinin \%58,59'unun erkek ve yaşlarının ortalama 35,09 yıl olduğu bulunmuştur. Kişiler ortalama 8,59 yıldır Bakanlıkta çalışmaktadır ve 5,90 yıldır kontrol görevlisidir. Çoğunluğunun $(\% 91,92)$ hizmet içi eğitim aldığ 1 belirlenirken, HACCP temel eğitimi $(\% 85,86)$ en çok katılımın sağlandığ 1 eğitim konusudur. Kișilerin \%64,65'i yaptı ğ ișten memnun olmasına karșın, resmi kontrolleri yeterli ve etkin bulanların oranı $\% 27,27$ ile çok düşük düzeydedir ve kişilerin $\% 38,38$ 'i idari yaptırım uygularken baskı altında hissettiğini belirtmiştir. Kontrol görevlilerinin kategorize edilmiş en önemli sorunları mevzuatla ilgili çok sık değişikliğin yapılması $(\% 74,75)$, resmi kontrollerle ilgili yeterli sayıda ekip/personelin olmamas1 $(\% 70,71)$, fiziki yapı ve ekipmanlarla ilgili Müdürlüğün kendine ait binası olmaması $(\% 36,36)$ ve iş ile ilgili diğer sorun olarak ücretlerin yetersizliğidir $(\% 59,60)$. Khi-kare testi sonucunda, resmi kontrolleri yeterli ve etkin bulma durumu ile kişilerin memleketleri, iş memnuniyetleri, 5996 sayılı kanunu gıda güvenliğini sağlamada yeterli bulma ve idari yaptırım uygularken baskı altında hissetme durumları arasında anlamlı ilişkilerin bulunduğu tespit edilmiştir. Kontrol görevlilerinin sorunlarının giderilmesi ve eğitimlerinin düzenli olması gıda güvenliğinin sağlanmasında katkısı olacaktır.

Turkish Journal Of Agriculture - Food Science And Technology, 4(12): 1061-1071, 2016

\section{The Determination of Socio-Economic Structure and Problems of Control Officers in Istanbul}

\section{A R T I C L E I N F O}

Article history:

Received 16 March 2016

Accepted 07 November 2016

Available online, ISSN: 2148-127X

Keywords:

Control officers

5996 numbered law

Chi-square test

Istanbul province

\section{*Corresponding Author:}

E-mail: farukadiguzel13@hotmail.com

\section{A B S T R A C T}

The aim of this study is to determine socio-economic properties and problems of the control officers in Istanbul province. The data are obtained via the questionnaire method from 99 control officers in the period of August-October 2015. As method, it is used to frequency, percent distributions and averages for personal and professional characteristics, opinions about related laws and categorized problems of control officers. Also, it is analyzed the relationship between sufficient and effective of official checking and some characteristics of control officers with Chi-square test $\left(X^{2}\right)$. It is determine that $58.59 \%$ of control officer are men and their averaged ages are 35.09. The people have been worked in the Ministry for 8.59 years and are control officers for 5.90 years in average. The majority of the people $(91.92 \%)$ have been got trained in-service, and HACCP basic training is the most participated issue $(85.86 \%)$. Although $64.65 \%$ of the people are satisfied with their jobs, the ratio of the people who consider with sufficient and effective of official checking is very low $(27.27 \%)$ and $38.38 \%$ of the people stated that feel coercion with applying administrative sanction. The most important categorized problems of control officers are amendments frequently in legislation (74.75\%), insufficient teams/officers in official controls $(70.71 \%)$, lack of own directorate buildings in physical structure and equipment $(36.36 \%)$ and insufficient payments in other job problem $(59.60 \%)$. It is determined with chi-square test that there were significant relationships between the sufficiency and effectiveness of official controls and homeland of persons, job satisfaction, sufficiency in providing food safety of 5996 numbered law, feeling coercion applying administrative sanction. Solution of control officers' problems and periodically training in food safety aspects could provide the contributions in food safety. 


\section{Giriş}

Sanayileşme ile birlikte genel yaşam döngüsü ve yaşayış içinde insanlık pek çok teknolojik ürüne ve yaşam standardına sahip olurken, doğal yaşam, çevre, beslenme ve sağlık adına pek çok olguyu da varsayılan hatta planlanan değerlere ve hedeflere göre hizla kaybetmektedir (Çağlarırmak, 2008). Dünya nüfusundaki hızlı artış, ürün ve servis ticaretinin globalleşmesi, iklim değişikliklerine paralel olarak gıda kaynaklarındaki azalma ve enerjinin verimli kullanım ihtiyacı gibi nedenlerin yanı sıra; yabancı yatırımların artması, tüketici güvenliğinin sağlanması, çevrenin korunması ve sosyal sorumluluklar, yeni icatlar ve teknolojilerin gelişmesi gıda sektöründe uluslararası standartlara olan talebi sürekli olarak artırmaktadır (Balçık Mısır, 2008).

Gıda güvencesi yeterli gıdaya fiziksel ve ekonomik olarak her zaman ulaşılabilmesi ile gıdanın kaliteli ve güvenli olması koşullarına bağlıdır. İnsanların aktif ve sağlıklı bir yaşam sürdürebilmesinin ise gıda güvencesinin sağlanması ile mümkün olduğu ifade edilmektedir (Ören ve ark., 2008). Bir başka şekilde söylenecek olursa, insanların sağlıkların koruyabilmeleri için yeterli ve dengeli beslenmeleri yanında, alınan gıdaların insan sağlığını tehdit etmemesi ve güvenli olması gerektiği de belirtilmektedir (Anonim, 2012b). Bu bağlamda, gıda güvenliği ve hijyen gibi konuların önemi günümüzde giderek artmaktadır (Anonim, 2012a). Dolayısıyla gıda ürünlerinin güvenli olmasının tüketicinin mutlak bir talebi olduğu (Erkmen, 2010) ve en temel hak ve özgürleri arasında yer aldığı ifade edilmektedir (Giray ve ark., 2006).

Gıda güvenliği güvenilir gıda üretimini sağlamak amacıyla hammadde temini, gıdaların üretimi, işlenmesi, depolanması, taşınması, dağıtımı ve sunulması aşamalarında gerekli tedbirlerin alınması olarak tanımlanmaktadır. Gıda güvenliğinin başlangıç noktası çiftlik, son noktası ise tüketici olarak kabul edilmektedir. Dolayısıyla gıda güvenliği, tüketime sunulan gıdaların çiftlikten sofraya gelinceye kadar geçirdikleri aşamaların tümünü kapsamaktadır (Giray ve Soysal, 2007). Hizlı nüfus artışı, üretimde yeni teknolojilerin kullanımı, toplumun değişen istek ve tüketim alışkanlıkları, toplu gıda ve yemek üretimindeki artış, gıdaların saklama süresinin artırılması, kontrol dışı gıda üretimi, çevre kirliliğii, eğitim ve gelir düzeyinin düşüklüğü, mevzuatın yeterince uygulanamaması, kontrol uygulamalarındaki eksiklikler gibi tehlikeler gıda güvenliğini tehdit etmektedir (Erkmen, 2010). Bu nedenle modern toplumun vazgeçilemez bir zorunluluğu olan gida güvenliğinin sağlanması için dünya genelinde otoriteler zaman içerisinde kısıtlamalar getirmekte ve çeşitli düzenlemeler yapmaktadırlar (Baş ve Deniz, 2015).

Dünyada gidaya yönelik ilk yasal düzenlemelere bakıldığında, ilk temel gida kanunları İtalya ve İngiltere'de 1860, Almanya'da 1861, Avusturya'da 1887 ve Fransa'da ise 1905 yılında yapıldığı görülmektedir (Kılıç, 2008). Gıda güvenliğinin sağlanmasına ilişkin önemli küresel çalışmaların ise 1900 'lerden sonra başladığı ifade edilmekte olup (Erbelet, 2014), bu anlamda 1945 yılında kurulan Gıda ve Tarım Örgütü (FAO) ile gıda güvenlik sistemi Birleşmiş Milletler himayesinde başlamıştır. Bu örgütün kuruluşundan kısa bir süre sonra 1948 yılında yine Birleşmiş Milletler bünyesinde küresel sağlık çalışmaları yapmak amaciyla Dünya Sağlık Örgütü (WHO) kurulmuştur (Yörük ve Güner, 2014). Sonrasında 1961 yılında ise Gida ve Tarım Örgütü (FAO) ve Dünya Sağlık Örgütü (WHO) ortaklaşa olarak gıda maddelerinin analizi, hijyen gereksinimleri, örnekleme, etiketleme, işlemeye ilişkin uluslararası standartlar oluşturarak gıda güvenilirliğini düzenlemek amaciyla Kodeks Alimentarius Komisyonu'nu kurmuşlardır. $\mathrm{Bu}$ komisyonun ana hedefleri gida gereksinimlerini ve tanımlarını sağlamak, bunların sağlanmasına rehber olmak ve ileri bir düzeye getirmek, bunların uyumuna yardımcı olmak ve böylece uluslararası ticareti kolaylaştırmaktır. Ayrıca, komisyon uluslararası hükümet ve sivil toplum örgütleri tarafindan yürütülen gıda standartları çalışmalarının koordinasyonunu da teşvik etmektedir (Erbelet, 2014). Daha sonra 1971 yilında bir konferansta şeffaf olarak tanitılan Tehlike Analizi ve Kritik Kontrol Noktası (Hazard Analysis and Critical Control Point-HACCP) sistemi, ilk defa 1972 yılında Amerika Birleşik Devletlerinde gıda ürünlerinin üretiminde kullanılmaya başlanmıştır. Avrupa Birliği (AB)'nin ise 2000 yılında yayınladığı beyaz doküman ile gıda konusunda merkezi bir yönetim benimsenmiş olup, 2002 y1linda The European Food Safety Authority (EFSA)'nın kurulması ile $\mathrm{AB}$ ülkeleri için gıda ve yem konusunda merkezi yönetime geçilmiştir. Son olarak 2005 yılında gıda güvenliği konusunda yayınlanan en son standart olan ISO 22000 yayınlanmıştır (Yörük ve Güner, 2014).

Dünyada bu gelişmeler yaşanırken, Türkiye'de ise gıda güvenliğine ilişkin ilk kanunun 1930 yılında çıkarılan 1580 sayılı Belediye Kanunu olduğu ifade edilmekte olup, bu kanun ile gıda üretim, satış ve depolama yerlerinin denetimi belediye sınırları içinde ve görevleri arasında sayılmıştır. Bu alandaki diğer bir kanun olan Belediye Kanunundan sonra 1930 yılında çıkarılan 1593 sayılı Umumi Hıfzı Sihha Kanunu ile insan sağllğına zarar verecek her türlü depolama, üretim vs. durumlar yasaklanmıştır (Giray ve Soysal, 2007). Devam eden yasal düzenlemeler ise, 1593 sayılı kanuna göre hazırlanan 1942 yılında çıkarılan Gıda Nizamnamesi ve gıda alanında yapılan ilk kapsamlı tüzük olan 1952 yılında çıkarılan Gıda Maddeleri Tüzüğüdür. Daha sonra 1954 yılında Türk Standartları Enstitüsünün kuruluşu ile ticarette standartlar getirilmiş ve bu değişimde gida sektörü önemli bir yer tutmuştur (Yörük ve Güner, 2014). 1961 yılında çıkarılan 224 sayılı kanunla Gıda Konseyi oluşturulmuş olup, gıda hijyen ve kontrolleri sağlik ocaklarına bırakılmıştır. 1971 yılında ise dönemin politika stratejileri çerçevesinde Tarım Bakanlığına bağlı ve daha sonra Gıda İşleri Genel Müdürlüğü adını alan İaşe Genel Müdürlüğü kurulmuş ve 1983 yılında kapatılmıştır (Erbelet, 2014). 1980 y1lında Sağlık ve Sosyal Yardım Bakanlığı tarafindan Gida Kontrol Hizmetlerini Yürütme Talimatı ile gayri sıhi müesseseler kontrol edilmeye başlanmıştır (Yörük ve Güner, 2014). 1995 yılı sonrasında Türkiye'nin $\mathrm{AB}$ ile yapmış olduğu Gümrük Birliği Anlaşmasının ardından gıda kanunu hazırlanmasına dair gıda taslağı resmi gazetede yayınlayarak yürürlüğe giren 560 sayılı Gıdaların 
Üretimi, Tüketimi ve Denetlenmesine Dair Kanun Hükmünde Kararname kabul edilmiştir. Gıdaların kontrol ve denetimiyle ilgili hususlar Tarım ve Köyişleri Bakanlığı ile Sağlık Bakanlığına verilmiş ve ilk defa HACCP kavramına risk yönetimi çerçevesinde değinilmiştir. 2004 yılında 5179 sayılı Gıdaların Üretimi, Tüketimi ve Denetlenmesine Dair Kanun Hükmündeki Kararnamenin Değiştirilerek Kabulü Hakkındaki Kanun çıkarılarak 560 sayılı düzenlemenin yerini almıştır. Bu düzenleme ile gıda güvenliğinin denetimi, kontrolü gibi hizmetler dağınık ve karmaşık görüntüden kurtarılarak yetkilerin tümü güncel adıyla Gıda Tarım ve Hayvancılık Bakanlığında toplanmıştır (Erbelet, 2014). Son olarak gıda ve yem güvenilirliğini, halk sağlığı, bitki ve hayvan sağlığı ile hayvan ıslahı ve refahını, tüketici menfaatlerini korumak ve sağlamak amacından hareketle gida denetiminde yetki karmaşasının giderilmesi ve AB'nin Gıda Kanunu ile ilgili hükümlerini düzenleyen 178/2002/EC Tüzüğü uygulamalarına tam uyumun sağlanması amacıyla hazırlanan 5996 sayılı Veteriner Hizmetleri, Bitki Sağlığı, Gıda ve Yem Kanunu 13 Aralık 2010 tarihinde yürürlüğe girmiştir (Akpınar, 2012).

Gıda güvenliği ile ilgili literatür incelendiğinde, gıda güvenliğinin tarihsel gelişimi ve mevcut durumu (Serpen, 2007; Alemdar, 2008; Çağlarırmak, 2008; Bayat, 2015; Yörük ve Güner, 2014), gida mevzuatı ve tarım politikasındaki yeri (Giray ve Soysal, 2007; Ören ve ark., 2008; Erbelet, 2014; Okur, 2015), işletme sorumlulukları, karşılaşılan riskler ve sorunlar (Erkmen, 2010; Akpınar, 2012; Erden, 2012), AB ile karşılaştırmalar (Halaç, 2002; Güneş ve Ünsal, 2006; Özbek ve Fidan, 2009; İba, 2013), tüketici davranışları (Topuzoğlu ve ark., 2007; Oral, 2009; Y1lmaz ve ark., 2009; Sharafkhani ve ark., 2010), g1da güvenlik sistemleri ve denetim hizmetleri (Yorulmaz, 2002; Erkan ve ark., 2008; Baş ve Deniz, 2015; Öksüztepe ve Beyazgül, 2015; Çopur ve ark., 2010) ile ilgili çeşitli çalışmaların yapıldığı görülmektedir. Tüketicilerin günlük hayatta çeşitli gida maddeleri ile karşı karşıya kaldığı dikkate alındığında, sağlık ve ekonomik yönlerden korunmak üzere gida kontrol hizmetleri önem kazanmıştır (Halaç, 2002). Günümüzde, Türkiye'de gıda işletmelerinin resmi kontrolleri Gıda Tarım ve Hayvancılık Bakanlığı bünyesinde ve kontrol görevlileri tarafından yapılmaktadır. Yani, kontrol görevlisi Bakanlık adına ön bildirim gereken haller dışında, haber verilmeksizin uygun sıklıkta risk esasına göre her türlü etkiden ve çıkar ilişkisinden uzak, tarafsız, objektif, bağımsız olarak izleme, gözetim, doğrulama, tetkik, denetim, numune alma ve analiz gibi uygulamalarını kapsayan resmi kontrolleri yapan kendisine verilen yetkiler çerçevesinde kanunda öngörülen idari yaptırımları uygulayan Bakanlık tarafından resmi kontrol yetkisi verilen kişi durumundadır (Anonim, 2016). Ancak, Türkiye'de gida güvenliği alanında kontrol hizmetini kamu adına üstlenen kişileri kapsayan çalışma bulunmadığı dikkate alındığında, gıda güvenliği konusunda kontrol görevlileri ile yapılan bu araştırma alandaki çalışmalara fayda sağlaması bakımından önemlidir. Gıda güvenliğinin her zaman güncel bir konu olması, kontrol görevlilerinin gida işletmelerinin resmi kontrollerinden sorumlu olması, İstanbul ili nüfusu dikkate alındığında, gıda arzı ve tüketimi, gıda işletmesi ve kontrol görevlisi sayısı bakımından ilk sırada olması ve bu konuda herhangi bir çalışma yapılmış olması araştırmayı orijinal kılmaktadır. $\mathrm{Bu}$ çerçevede araştırmanın amacı, İstanbul ilindeki kontrol görevlilerinin sosyo-ekonomik yapılarının, mevzuat hakkındaki düşüncelerinin ve sorunlarının belirlenmesi ile kontrol görevlilerinin bazı özellikleri ile resmi kontrolleri yeterli ve etkin bulma durumu arasındaki ilişkilerin tespitidir.

\section{Materyal ve Metot}

Araştırmanın ana materyalini, İstanbul İlinde 5996 sayılı Veteriner Hizmetleri, Bitki Sağlığı, Gıda ve Yem Kanunu kapsamında çalışan kontrol görevlilerinden 2015 yılı Ağustos ve Ekim aylarında anket yöntemi kullanılarak elde edilen veriler oluşturmuştur. İlk olarak Gıda, Tarım ve Hayvancılık Bakanlığı'nın Gıda Güvenliği Bilgi Sistemi'nden (GGBS) İl Müdürlüğü ve 39 İlçe Müdürlüğündeki kontrol görevlilerinin listesi elde edilmiştir (Anonim, 2015). Mevcut liste incelendiğinde, il genelindeki kontrol görevlilerinin çoğunlukla (\%98.00) sırasıyla ziraat ve gida mühendisliği ile veteriner hekimlik branşlarındaki kişilerden oluştuğu tespit edilmiştir. Kalanı ise kimya ve su ürünleri mühendisliği ile kimyagerlik mesleği mensubu kişilerdir. Daha sonra, tesadüfî olmayan örnekleme yöntemlerinden gayeli örnekleme yöntemi ile seçilen (Çiçek ve Erkan, 1996) ildeki toplam kontrol görevlisi sayısının \%20'sini oluşturan 99 adet kontrol görevlisi araştırmanın örnek hacmi olarak belirlenmiştir. Örnek hacmi çoğunlukla bulunan kontrol görevlisi branşlarına göre oransal olarak dağıtılmış olup, anket uygulaması İl Müdürlüğü ve 39 ilçe müdürlüğündeki kişilerin katılımı ile gerçekleştirilmiştir. $\mathrm{Bu}$ verilerin yanında, gıda güvenliği ile ilgili olarak daha önce yapılmış yayınlardan ikincil materyal olarak yararlanılmıştır.

Metot olarak öncelikle kontrol görevlilerinin sosyoekonomik yapılarını belirlemek amacıyla kişisel özellikler, meslek ile ilgili özellikler ve 5179 sayılı Gıdaların Üretimi, Tüketimi ve Denetlenmesine Dair Kanun Hükmünde Kararnamenin Değiştirilerek Kabulü Hakkında Kanun ile 5996 sayılı Veteriner Hizmetleri, Bitki Sağlığı, Gıda ve Yem Kanunu hakkındaki düşünceler sunulmuştur. Kontrol görevlilerinin 5996 sayılı Kanunun "Gıda ve Yem" başlıklı beşinci kısımdaki seçilmiş hükümlerine ilişkin görüşleri Likert tipi ölçek ile ölçeklendirilmiştir. Kişilerin ilgili hükümlere "1=Kesinlikle Katılmiyorum, 2=Katılmiyorum, 3=Kararsızım, 4=Katılıyorum, 5=Kesinlikle Katılıyorum" olmak üzere cevaplandırmaları istenmiş olup, seçilmiş hükümlere ilişkin değerlendirmelerin ortalaması 4'ün altında olan yani görüşlerinin olumsuz olduğu hükümler sunulmuş ve yorumlanmıştır. Ayrıca, kontrol görevlilerinin sorunları gıda mevzuatı, resmi kontroller, fiziki yapı ve ekipmanlar ve iş ile ilgili diğer sorunlar şeklinde kategorize edilerek irdelenmeye çalışılmıştır. Bu veriler, frekans ve yüzde dağılımlar ile basit aritmetik ortalamalar şeklinde verilmiştir. Araştırmada kontrol görevlilerinin bazı sosyo-ekonomik özellikleri ile resmi kontrolleri yeterli ve etkin bulma durumu arasında herhangi bir ilişki olup olmadığı yapılan Khi-kare $\left(X^{2}\right)$ testi ile analiz edilmiştir (Gujarati, 1995; Mirer, 1995). Test sonucunda sadece aralarında istatistiksel olarak anlamlı ilişki bulunduğu tespit edilen değişkenler 
yorumlanmıştır. Ayrıca, Khi-kare testi ile ölçülen ilişkilerin anlamlı olduğu durumlarda bu ilişkinin ne oranda güçlü olduğunu test etmek amacı ile kullanılan Bağımlılık Katsayısı da (Coefficient of Contingency) hesaplanmıştır (Düzgüneş ve ark., 1983).

\section{Bulgular ve Tartışma}

\section{Kontrol Görevlilerinin Sosyo-Ekonomik Yapıları}

Kontrol görevlilerinin sosyo-ekonomik özelliklerine ilişkin bilgiler Çizelge 1'de verilmiştir. Ankete katılan kontrol görevlilerinin çoğunluğu erkektir $(\% 58,59)$ ve yaşları ortalama olarak 35,09 yıl olarak hesaplanmış olup, genç yaştaki bireylerden oluştuğu belirlenmiştir. Kontrol görevlilerinin \%40,40’ını, en yüksek oranla ziraat mühendisleri oluşturmaktadır. Çoğunluğunun memleketleri Karadeniz $(\% 26,27)$ ve İç Anadolu $(\% 25,25)$ Bölgeleridir. Kontrol görevlilerinin İstanbul ilinde yaşama süresi ortalama olarak 11,38 yıl olarak bulunmuş olup, Bakanlıkta çalışma süreleri dikkate alındığında kişilerin öğrencilik veya ailenin ikameti gibi nedenlerle daha öncesinde de şehirde bulunduklarını göstermektedir. Ayrıca, kişilerin yarısından fazlasının $(\% 52,53)$ çalışılan ilçede ikamet ettikleri belirlenmiştir. $\mathrm{Bu}$ durum kişilerin ulaşım problemini azaltma isteği ile açıklanabilir. Kişilerin yaklaşık üçte birinin $(\% 29,29)$ lisansüstü öğrenim gördüğü belirlenirken, lisansüstü öğrenim görenlerin çoğunluğu $(\% 89,66)$ yüksek lisans derecesine sahiptir. Kontrol görevlilerinin \%69,70'i evlidir ve eşleri çoğunlukla lisans $(\% 57,97)$ mezunu olup, meslekleri memur $(\% 52,17)$ olan kişilerdir. Kişilerin aileleri ortalama üç kişiden oluşmaktadır ve ailede çalışan birey sayısı ortalama iki kişidir. Ailelerin aylık gelirleri ortalama olarak yaklaşık 5.500 TL olup, gelirin \%80,60’1 harcanmaktadir. $\mathrm{Bu}$ durum ailelerin tasarruf yapma imkânlarının çok az olduğunu göstermektedir. Kişilerin yarısından fazlası $(\% 53,54)$ kiracıdır ve kira harcaması aylık gelirlerinin yaklaşık beşte birini oluşturmaktadır. Kontrol görevlilerinin \%60,61'inin otomobili bulunmakta olup, otomobili olanların yaklaşık yarısı $(\% 48,33)$ işe otomobille gitmektedir. Kişilerin sosyo-ekonomik özelliklerinin, geçim ve gelecek kaygılarının yapılan işin niteliğini etkileyebileceği göz önünde bulundurulmalıdır.

\section{Kontrol Görevlilerinin Meslek ile İlgili Özellikleri}

Türkiye'de g1da güvenliğinin temini için işletmelerin resmi kontrolleri kendilerine Bakanlıkça eğitim verilerek görevlendirilen ve kimlik kartı düzenlenen personel tarafından yapılmaktadır. Kontrol görevlilerinin meslek ile ilgili özellikleri Çizelge 2'de sunulmuştur. Kişilerin bakanlıkta çalışma süresi ortalama 8,59 y1l olarak hesaplanırken, yaklaşık yarısının $(\% 49,50) 5$ yıl ve daha az süre ile çalıştığı tespit edilmiştir. Kontrol görevlilerinin yarısından fazlası $(\% 59,60)$ bakanlık öncesi özel sektörde meslekleri ile ilgili işlerde çalıştıklarını ifade etmiştir. G1da ve yem şubesinde çalışma süresi ortalama 6,06 yıl olup, kişilerin ortalama 5,90 yıldır kontrol görevlisi olduğu bulunmuştur. Gerek Bakanlıkta gerekse ilgili şubede ve kontrol görevlisi olarak çalışma süresi dikkate alındığında, İstanbul ilindeki ilçe sayısının yapılan yasal düzenleme ile 39 ilçeye yükseltilmesi, Bakanlığın yeniden yapılanma süreci ile yeni ilçe müdürlüklerinin kurulması ve 5996 sayılı kanunun yürürlüğe girmesi ile birlikte Bakanlığın ciddi sayılabilecek bir personel istihdamı gerçekleştirdiği anlaşılmaktadır. Bakanlığın diğer birimlerinde çalıştığını söyleyenlerin oranı \%33,33 olarak hesaplanırken, İl Müdürlüklerinin diğer şubeleri, araştırma enstitüleri, g1da kontrol laboratuvarları ve üretme istasyonları çalışılan diğer birimlerdir. Kişilerin tamamına yakınının $(\% 91,92)$ hizmet içi eğitim aldığ belirlenirken, \%85,86'sının HACCP Temel Eğitimi, \%63,64'ünün HACCP Tetkik Eğitimi ve \%37,37'sinin Organik Tarım Eğitimi aldığı tespit edilmiştir. Bu durum, eğitimlerin resmi kontrol yapılabilmesi için zorunluluk olması ile açıklanabilir. Ayrıca, 5996 sayılı kanunun yürürlüğe girdiği tarih ve kontrol görevlisi olarak çalışılan süre ile eğitimlere katılma zamanı arasında oluşan süre fark1 görevlilerin ve resmi kontrollerin etkinliği bakımından önemlidir. Bununla birlikte, personel eğitimlerinin düzenli olması ve süreklilik arz etmesi gıdaların daha iyi denetlenmesini sağlayarak gıdalardan kaynaklanabilecek sağlık sorunlarını önlemeye yardımcı olabilecektir. GGBS, g1da kodeksi, et hijyeni, resmi veteriner hekimlik, iş sağlığı ve güvenliği ile proje döngüsü eğitimleri kontrol görevlilerinin \%15,15'inin katıldığı diğer hizmet içi eğitimlerdir. Ayrıca, kişilerin çoğunluğunun $(\% 60,61)$ yaptığı işten memnun olmasına karşın, \%35,35'inin bu konuda olumlu görüş beyan etmemesi dikkat çekicidir.

\section{Kontrol Görevlilerinin Kanunlar Hakkındaki}

\section{Düşünceleri}

Gıda güvenliğinin sağlanmasında ilgili mevzuatın uygulanması aşamasında sahada görevli olan kontrol görevlilerinin yasal düzenlemeler hakkındaki görüşlerinin ortaya konulması işleyişin değerlendirilmesi, eksikliklerin belirlenmesi ve giderilmesine olanak vermesi bakımından önemlidir. Kontrol görevlilerinin 5179 ve 5996 sayılı kanunlar hakkındaki düşünceleri Çizelge 3'de verilmiştir. Kişilerin yaklaşık yarısının $(\% 46,47) 5179$ sayılı kanunu incelediği tespit edilmiştir. 5179 sayılı kanunda görevli olduğunu söyleyenlerin oranı ise \%36,36 olarak hesaplanmıştır. Kontrol görevlilerinin \%37,38'inin 5179 sayılı kanunu tutarlı bulmadıkları belirlenirken, kişilerin $\% 57,58$ 'i gıda güvenliğini sağlama konusunda 5996 sayılı kanunu önceki kanuna göre yeterli bulmaktadır. Gıda güvenliğinin ön planda olması, işletmelerin faaliyete geçmeden önce denetlenerek üretim izinlerinin verilmesi, mevzuatın daha sade, net ve anlaşılır olması, yoruma ihtiyaç göstermemesi, ülke şartlarına uygun olması, idari yaptırımların üretim işletmeleri için caydırıcı olması, teknik ve hijyen şartlarının daha ayrıntılı olması kontrol görevlileri tarafindan 5179 sayılı kanunun üstünlükleri olarak görülmesine karşın, üretim işletmeleri için izin belgelerinin alınmasının zorluğu nedeniyle merdiven altı işletmelerin engellenememesi, bürokratik işlemlerin çok olması ve etkin bir bilgi sisteminin olmaması kanunun eksiklikleri olarak değerlendirilmiştir. Kişilerin çoğunluğu $(\% 85,86) 5996$ sayılı kanunu önceki kanuna tercih etmektedir. 5996 sayılı kanunu tutarlı bulanların oranı \%64,65 olarak hesaplanmıştır. Kontrol görevlileri 5996 sayılı kanunun AB başta olmak üzere uluslararası normlara yakın ve güncel olarak gıda güvenliğine önem vermesi, kapsamının geniş olması, yatay ve dikey çok sayıda mevzuatla desteklenmesi, her kabahatin bir yaptırım karşılığı olması, yaptırımların caydırıcı olması, gıda güvenliğinin sağlanmasının işletmecilerin sorumluluğuna birakılması, kontrol görevlilerinin yetkilerinin net olması, uygunsuz işletmeler konusunda kamuoyunun bilgilendirilmesi, laboratuvar gibi 
destekleyici kurumların daha iyi çalışması ve GGBS ile Alo Gıda 174 şikâyet hattı vb. hizmetlerinin olması gibi üstünlüklerinin bulunduğunu ifade etmektedirler. Ancak, mevzuatta çok sık değişiklik yapılması, çelişkilerin ve belirsizliklerin bulunması nedeniyle işleyiş ve uygulamada yaşanan farklılıklar, diğer ülke mevzuatlarının baz alınması, ülkenin yapısı ve şartlarının yeterince göz önünde bulundurulmaması, idari yaptırımların işleyişinin çok zaman alması ve işletme büyüklüğüne göre uygulanmaması, şikâyet hakkının kullanımında sorumluluk bulunmaması, ürün etiketinin içeriğinden çok önemsenmesi, istihdamı zorunlu personel bulundurma kriterinin sınırının genişletilmesi ve çalıştırmama nedeniyle uygulanan yaptırımın caydırıcı olmaması 5996 sayılı kanunun eksiklikleri olarak görülmektedir. Kontrol görevlilerinin çok azının $(\% 11,11)$ 5996 sayılı kanunu gıda güvenliğini sağlamada yeterli bulmadıkları tespit edilirken, kısmen yeterli bulanların oranı \%56,57 ile en yüksek düzeydedir. Ayrıca, tüketici ve işletmecilerin gıda güvenliği konusunda yeterli bilince sahip olmadıkları ve eğitimlerinin yetersiz olduğu düşünülmektedir. Resmi kontrolleri yeterli ve etkin bulanların oranı \%27,27 ile düşük düzeyde olup, kontrol görevlilerinin \%38,38'nin yasal işlem uygularken bask1 altında hissettiği ve en önemli baskı unsurunun işletme yetkilisi $(\% 78,95)$ olduğu bulunmuştur. Ayrıca, kontrol görevlilerinin idari yaptırımların tutarını küçük işletmeler için yüksek bulması nedeniyle duygusal olarak vicdanen baskı altında hissettikleri tespit edilmiştir.

Çizelge 1 Sosyo-ekonomik özellikler

\begin{tabular}{|c|c|c|c|}
\hline \multicolumn{2}{|c|}{ Özellikler } & Frekans & $\%$ \\
\hline \multirow{3}{*}{ Cinsiyet } & Erkek & 58 & 58,59 \\
\hline & Kadın & 41 & 41,41 \\
\hline & Ziraat Mühendisi & 40 & 40,40 \\
\hline \multirow{2}{*}{ Meslek } & Gıda Mühendisi & 36 & 36,37 \\
\hline & Veteriner Hekim & 23 & 23,23 \\
\hline \multicolumn{2}{|l|}{ Yaş Ortalaması (yıl) } & \multicolumn{2}{|c|}{35,09} \\
\hline \multirow{7}{*}{ Memleket } & Karadeniz & 26 & 26,27 \\
\hline & İç Anadolu & 25 & 25,25 \\
\hline & Marmara & 15 & 15,15 \\
\hline & Akdeniz & 11 & 11,11 \\
\hline & Ege & 8 & 8,08 \\
\hline & Doğu Anadolu & 7 & 7,07 \\
\hline & Güneydoğu Anadolu & 7 & 7,07 \\
\hline \multicolumn{2}{|l|}{ İlde Ortalama Yaşama Süresi (yıl) } & \multicolumn{2}{|c|}{11,38} \\
\hline \multirow{2}{*}{ İkamet Edilen İlçe } & Çalışılan İlçe İle Aynı & 52 & 52,53 \\
\hline & Çalışılan İlçe İle Farklı & 47 & 47,47 \\
\hline \multirow{2}{*}{ Lisansüstü Öğrenim Durumu } & Evet & 29 & 29,29 \\
\hline & Hayır & 70 & 70,71 \\
\hline \multirow{2}{*}{ Lisansüstü Öğrenim Derecesi } & Yüksek Lisans & 26 & 89,66 \\
\hline & Doktora & 3 & 10,34 \\
\hline \multirow{2}{*}{ Medeni Hal } & Bekâr & 30 & 30,30 \\
\hline & Evli & 69 & 69,70 \\
\hline \multirow{5}{*}{ Eş Öğrenim Durumu } & Lise & 8 & 11,59 \\
\hline & Ön Lisans & 4 & 5,80 \\
\hline & Lisans & 40 & 57,97 \\
\hline & Yüksek Lisans & 16 & 23,19 \\
\hline & Doktora & 1 & 1,45 \\
\hline \multirow{6}{*}{ Eş Meslek Grupları } & Memur & 36 & 52,17 \\
\hline & Serbest Meslek & 18 & 26,09 \\
\hline & Ev Hanımı & 7 & 10,14 \\
\hline & İşçi & 6 & 8,70 \\
\hline & Esnaf & 1 & 1,45 \\
\hline & Emekli & 1 & 1,45 \\
\hline \multirow{4}{*}{\multicolumn{2}{|c|}{$\begin{array}{l}\text { Ailedeki Ortalama Birey Sayısı (kişi) } \\
\text { Ailedeki Ortalama Çalışan Birey Sayısı (kişi) } \\
\text { Ortalama Aile Geliri (TL/ay) } \\
\text { Ortalama Aile Harcaması (TL/ay) }\end{array}$}} & 3,17 & \\
\hline & & 1,91 & \\
\hline & & 5457,37 & \\
\hline & & 4398,84 & \\
\hline \multirow{2}{*}{ Oturulan Evin Mülkiyeti } & Kira & 53 & 53,54 \\
\hline & Kendi Evi & 46 & 46,46 \\
\hline \multicolumn{2}{|l|}{ Ortalama Kira Bedeli (TL/ay) } & 1009,15 & \\
\hline \multirow{2}{*}{ Otomobil Olma Durumu } & Var & 60 & 60,61 \\
\hline & Yok & 39 & 39,39 \\
\hline \multirow{2}{*}{ İşe Otomobil İle Gitme Durumu } & Evet & 29 & 48,33 \\
\hline & Hayır & 31 & 51,67 \\
\hline
\end{tabular}


Çizelge 2 Meslek ile ilgili özellikler

\begin{tabular}{|c|c|c|c|c|}
\hline \multicolumn{2}{|l|}{ Özellikler } & Frekans & $\%$ & Ortalama \\
\hline \multirow{4}{*}{ Bakanlık Çalışma Süresi (yıl) } & $\leq 5$ & 49 & 49,50 & 3,76 \\
\hline & $6-10$ & 27 & 27,27 & 8,44 \\
\hline & $\geq 11$ & 23 & 23,23 & 19,04 \\
\hline & Toplam & 99 & 100,00 & 8,59 \\
\hline \multirow{2}{*}{ Bakanlık Öncesi Çalışma Durumu } & Evet & 59 & 59,60 & - \\
\hline & Hayır & 40 & 40,40 & - \\
\hline \multirow{4}{*}{ Gıda ve Yem Şubesi Çalışma Süresi (yıl) } & $\leq 5$ & 63 & 63,64 & 3,70 \\
\hline & $6-10$ & 23 & 23,23 & 7,65 \\
\hline & $\geq 11$ & 13 & 13,13 & 14,69 \\
\hline & Toplam & 99 & 100,00 & 6,06 \\
\hline \multirow{2}{*}{ Diğer Birimlerde Çalışma Durumu } & Evet & 33 & 33,33 & - \\
\hline & Hayır & 66 & 66,67 & - \\
\hline \multirow{4}{*}{ Kontrol Görevlisi Olarak Çalışma Süresi (yıl) } & $\leq 5$ & 63 & 63,64 & 3,65 \\
\hline & $6-10$ & 23 & 23,23 & 7,43 \\
\hline & $\geq 11$ & 13 & 13,13 & 14,08 \\
\hline & Toplam & 99 & 100,00 & 5,90 \\
\hline \multirow{2}{*}{ Hizmet İçi Eğitim Alma Durumu } & Evet & 91 & 91,92 & - \\
\hline & Hayır & 8 & 8,08 & - \\
\hline \multirow{2}{*}{ HACCP Temel Eğitimi } & Evet & 85 & 85,86 & - \\
\hline & Hayır & 14 & 14,14 & - \\
\hline \multirow{3}{*}{ HACCP Temel Eğitimi Zamanı } & 2010 Öncesi & 10 & 11,77 & 7,80 \\
\hline & 2010 Y1lı Sonrası & 45 & 52,94 & 1,87 \\
\hline & Cevap Yok & 30 & 35,29 & - \\
\hline HACCP & Evet & 63 & 63,64 & - \\
\hline Tetkik Eğitimi & Hayır & 36 & 36,36 & - \\
\hline \multirow{3}{*}{ HACCP Tetkik Eğitimi Zamanı } & 2010 Öncesi & 0 & 0,00 & - \\
\hline & 2010 Y1lı Sonrası & 43 & 68,25 & 1,23 \\
\hline & Cevap Yok & 20 & 31,75 & - \\
\hline \multirow{2}{*}{ Organik Tarım Eğitimi } & Evet & 37 & 37,37 & - \\
\hline & Hayır & 62 & 62,63 & - \\
\hline \multirow{3}{*}{ Organik Tarım Eğitimi Zamanı } & 2010 Öncesi & 3 & 8,11 & 7,33 \\
\hline & 2010 Y1lı Sonras1 & 19 & 51,35 & 3,05 \\
\hline & Cevap Yok & 15 & 40,54 & - \\
\hline \multirow{2}{*}{ Alınan Diğer Eğitimler } & Evet & 15 & 15,15 & - \\
\hline & Hayır & 84 & 84,85 & - \\
\hline \multirow{3}{*}{ Diğer Eğitimlerin Süresi } & 2010 Öncesi & 4 & 26,67 & 8,50 \\
\hline & 2010 Y1lı Sonras1 & 5 & 33,33 & 1,40 \\
\hline & Cevap Yok & 6 & 40,00 & - \\
\hline \multirow{6}{*}{ İş Memnuniyeti } & Hiç Memnun Değilim & 6 & 6,06 & - \\
\hline & Memnun Değilim & 11 & 11,11 & - \\
\hline & Belirsiz & 18 & 18,18 & - \\
\hline & Memnunum & 60 & 60,61 & - \\
\hline & Çok Memnunum & 4 & 4,04 & - \\
\hline & Toplam & 99 & 100,00 & 3,45 \\
\hline
\end{tabular}

Kontrol görevlilerinin 5996 sayılı kanunun "Gıda ve Yem" başlıklı kısımdaki seçilmiş hükümlerine ilişkin görüşleri incelenmiş ve olumsuz görüşlerinin bulunduğu tespit edilmiştir. $\mathrm{Bu}$ görüşler hakkındaki değerlendirmelerin ortalaması 4'ün altında olan hükümlere ilişkin bilgiler Çizelge 4'de verilmiştir. Çizelgedeki ilk hükümle ilgili olarak kişilerin \%3,03'ünün bu hükme kesinlikle katılmadığı, \%11,11'inin katılmadığ 1 ve \%20,20'sinin kararsız olduğu yani olumlu görüşlerinin bulunmadığı belirlenmiştir. Kişilerin olumsuz görüşlerinin belirtilen ürünün geri kalanının güvenilir olup olmadığının ispatının nasıl yapılacağı konusundaki belirsizlikten kaynaklanabileceğini düşündürmektedir. İkinci hüküm olan gıda ve yemin bu mevzuat hükümlerini kapsadığı ölçüde güvenilir kabul edilmesi hükmüne kişilerin $\%$ 7,07'sinin katılmadı̆̆ı ve \%23,23'ünün kararsız görüş bildirdiği tespit edilmiş olup, gıda güvenliğinin ölçüsü konusundaki belirsizlik nedeni ile olumsuz görüşleri olduğu düşünülmektedir. Çizelgedeki üçüncü, dördüncü ve beşinci hükümlerle ilgili olarak kişilerin sırasıyla $\% 36,36, \% 31,31$ ve \%33,33'ünün olumsuz görüşlerinin bulunduğu belirlenirken, diğer kurumlarla yetki paylaşımı ile işbirliği, yetki devri, hizmet alımı konularına sıcak bakılmadığı anlaşılmaktadır. Resmi kontrollerde tekniker, teknisyen ve yardımcı sağlık personelinin kontrolöre yardımcı olmak üzere görev alabilmesi hükmüne kişilerin \%6,06'sının kesinlikle katılmadığ1, \%10,10'unun katılmadığı ve \%8,08'inin kararsız görüş beyan ettiği saptanmıştır. 5996 sayılı kanunun Ek-2'sinde "Üretim, İşleme ve Dağıtım Aşamalarında Resmi Kontrollerden Sorumlu Meslek Mensupları" açıklanmakta ve "Gıdanın Resmi Kontrolü ve İdari Yaptırımlar Prosedürü’nde resmi kontrollerin gida üretim yerleri için en az 2, satış ve toplu tüketim yerlerinde 1 adet kontrol görevlisi ile gerçekleştirileceği belirtilmektedir. Yardımcı personele 
satış ve toplu tüketim işletmelerinin resmi kontrollerinde ve kontrol görevlisinin tek başına göreve çıktığı durumlarda ihtiyaç duyulmaktadır. İldeki ortalama kontrol görevlisi sayısı da dikkate alındığında, kişilerin bu hükme olumsuz görüşleri ilgili personellere ihtiyaç duyulmaması ve etkinliklerinin az olması düşüncesi ile açıklanabilir.
Kanunun Bakanlığın, kesimhanelerde ve et parçalama işlemi yapılan yerlerde resmi veya yetkilendirilmiş veteriner hekim görevlendirmesi hükmüne kişilerin \%3,03'ünün kesinlikle katılmadı̆̆ 1 \% \%,05'inin katılmadığ1 ve \%21,21'inin kararsız görüş bildirdiği belirlenmiştir.

Çizelge 3 Kanunlar hakkındaki düşünceler

\begin{tabular}{|c|c|c|c|}
\hline \multicolumn{2}{|l|}{ Özellikler } & \multirow{2}{*}{$\begin{array}{c}\text { Frekans } \\
26\end{array}$} & \multirow{2}{*}{$\begin{array}{c}\% \\
26,26\end{array}$} \\
\hline \multirow{3}{*}{5179 Sayılı Kanun Hakkındaki Bilgi Durumu } & Sadece Duydum & & \\
\hline & 5996'dan Ö́nceki Kanun & 27 & 27,27 \\
\hline & İnceledim & 46 & 46,47 \\
\hline \multirow{2}{*}{5179 Sayılı Kanunda Görevli Olma Durumu } & Evet & 36 & 36,36 \\
\hline & Hayır & 63 & 63,64 \\
\hline \multirow{3}{*}{5179 Sayılı Kanunu Tutarlı Bulma Durumu } & Evet & 27 & 27,27 \\
\hline & Hayır & 37 & 37,38 \\
\hline & Fikrim Yok & 35 & 35,35 \\
\hline \multirow{3}{*}{ Gıda Güvenliği Sağlama Konusunda } & 5996 Sayılı Kanun Daha İyi & 57 & 57,58 \\
\hline & 5179 Sayılı Kanun Daha İyi & 14 & 14,14 \\
\hline & Fikrim Yok & 28 & 28,28 \\
\hline \multirow{2}{*}{ Kanun Tercihi } & 5179 Sayılı Kanun & 14 & 14,14 \\
\hline & 5996 Sayılı Kanun & 85 & 85,86 \\
\hline \multirow{2}{*}{5996 Sayılı Kanunu Tutarlı Bulma Durumu } & Evet & 64 & 64,65 \\
\hline & Hayır & 35 & 35,35 \\
\hline \multirow{3}{*}{5996 Sayılı Kanunun Gıda Güvenliğini Sağlama Durumu } & Evet & 32 & 32,32 \\
\hline & Kismen & 56 & 56,57 \\
\hline & Hayır & 11 & 11,11 \\
\hline \multirow{2}{*}{ Kontrolleri Yeterli ve Etkin Bulma Durumu } & Evet & 27 & 27,27 \\
\hline & Hayır & 72 & 72,73 \\
\hline \multirow{2}{*}{ Baskı Altında Hissetme Durumu } & Evet & 38 & 38,38 \\
\hline & Hayır & 61 & 61,62 \\
\hline \multirow{4}{*}{ Baskı Unsurları* } & İşletme Yetkilisi & 30 & 78,95 \\
\hline & Siyasi & 15 & 39,47 \\
\hline & İdari & 14 & 36,84 \\
\hline & Vicdani & 8 & 21,05 \\
\hline
\end{tabular}

*Birden çok cevap verildiği için toplam \%100’ü geçmektedir.

Çizelge 4 Kontrol görevlilerinin 5996 Sayılı Veteriner Hizmetleri, Bitki Sağlı̆̆ı, Gıda ve Yem Kanunu'nun seçilmiş hükümlerine ilişkin görüşleri

\begin{tabular}{|c|c|c|c|c|c|c|}
\hline \multirow{2}{*}{ Hükümler } & \multicolumn{5}{|c|}{ Hükümlere Katılma Durumu $(\%)^{*}$} & \multirow{2}{*}{ Ortalama* } \\
\hline & 1 & 2 & 3 & 4 & 5 & \\
\hline $\begin{array}{l}\text { 1. Bir seri, parti veya sevkiyattaki aynı sınıf veya çeşit gıda ve } \\
\text { yemin bir bölümünün güvenilir olmadığının tespiti durumunda, } \\
\text { geri kalanının güvenilir olduğu ispat edilemez ise, tamamının } \\
\text { güvenilir olmadığının kabul edilmesi }\end{array}$ & 3,03 & 11,11 & 20,20 & 45,46 & 20,20 & 3,69 \\
\hline $\begin{array}{l}\text { 2. Gıda ve yemin bu mevzuat hükümlerini kapsadığı ölçüde } \\
\text { güvenilir kabul edilmesi }\end{array}$ & 0,00 & 7,07 & 23,23 & 49,50 & 20,20 & 3,83 \\
\hline $\begin{array}{l}\text { 3. Katkı, aroma, zenginleştirme amaçlı madde ilaveli kaynak ve } \\
\text { içme suları, doğal mineralli sular ile yapay sodalara ilişkin usul ve } \\
\text { esasların Bakanlıkça; kaynak ve içme suları, doğal mineralli ve } \\
\text { tıbbi amaçlı sular ile içme-kullanma suları için Sağlık } \\
\text { Bakanlığınca belirlenmesi }\end{array}$ & 5,05 & 10,10 & 21,21 & 46,47 & 17,17 & 3,61 \\
\hline $\begin{array}{l}\text { 4. Takviye edici gıdalara ilişkin usul ve esasların Bakanlıkça; özel } \\
\text { tıbbî amaçlı diyet gıdalar için Sağlık Bakanlığınca belirlenmesi }\end{array}$ & 7,07 & 14,14 & 10,10 & 47,48 & 21,21 & 3,62 \\
\hline $\begin{array}{l}\text { 5. Bakanlığın gerektiğinde diğer kurum ve kuruluşları ile işbirliği } \\
\text { yapabilmesi, görev ve yetkilerini devredebilmesi, hizmet alımı } \\
\text { yapabilmesi }\end{array}$ & 7,07 & 9,09 & 17,17 & 49,50 & 17,17 & 3,61 \\
\hline $\begin{array}{l}\text { 6. Resmî kontrollerde tekniker, teknisyen ve yardımcı sağlık } \\
\text { personelinin kontrolöre yardımcı olmak üzere görev alabilmesi }\end{array}$ & 6,06 & 10,10 & 8,08 & 48,49 & 27,27 & 3,81 \\
\hline $\begin{array}{l}\text { 7. Bakanlığın, kesimhanelerde ve et parçalama işlemi yapılan } \\
\text { yerlerde resmî veya yetkilendirilmiş veteriner hekim } \\
\text { görevlendirmesi }\end{array}$ & 3,03 & 5,05 & 21,21 & 49,50 & 21,21 & 3,81 \\
\hline $\begin{array}{l}\text { 8. Bakanlığın yürütülen faaliyetler ve yapılan resmî kontrollerin } \\
\text { karşılığı olarak ücret alabilmesi }\end{array}$ & 9,09 & 10,10 & 15,15 & 40,40 & 25,26 & 3,63 \\
\hline
\end{tabular}


Olumsuz görüşlerin gerek iş yükü artışı gerekse yetki devrine sicak bakmama nedenlerinden olabileceği düşünülmektedir. Bakanlığın yürütülen faaliyetler ve resmi kontroller karşılığı ücret alabilmesi hükmüne kişilerin \%9,09'unun kesinlikle katılmadığı, \%10,10'unun katılmadığ 1 belirlenirken, \%21,21'nin bu konudaki görüşlerinin kararsız olduğu bulunmuştur. Kişilerin olumsuz görüşlerinin nedeni yürütülen faaliyetlerden ziyade resmi kontrollerden ücret alınabilmesinin işletmelere maddi yük getirebileceği düşüncesi olabilir

\section{Kontrol Görevlilerinin Sorunlart}

Gıda güvenliğinin devlet tarafindan oluşturulan mevzuat, gıda üreticileri ve pazarlamacıları tarafindan kullanılan bilimsel ve teknolojik birikim ile tüketici tarafından oluşturulan kamuoyundan oluştuğu belirtilmekte olup, etkin bir g1da güvenliği oluşturulabilmesi için bu üç unsurun sorumluluklarını yerine getirmesi gerektiği ifade edilmektedir (Bayrak ve İlbeği, 1997). Bu bakımdan gida işletmelerinin devletin yasal düzenlemelerle temin etmeye çalıştığı gıda güvenliğine uygunluğunu resmi kontroller vasitasıyla tespitinden sorumlu kontrol görevlilerinin sorunlarının belirlenmesi ve giderilmesi yapılan işin niteliğine olumlu etki yapabilecektir.

Kontrol görevlilerinin sorunlarına ilişkin bilgiler kategorize edilerek Çizelge 5'de sunulmuştur. Mevzuatta çok sık değişiklik yapılması $(\% 74,75)$ ve mevzuatın anlaşılmasında güçlük yaşanması ve yoruma açık olması $(\% 70,71)$ kişilerin karşılaştığ 1 gıda mevzuatı ile ilgili en önemli sorunlardır. Mevzuatın güncel ihtiyaçlara ve bilimsel sonuçlara göre revize edildiği varsayımı ile hareket edilmesi gerekmekle birlikte, mevzuatta yapılan sık değişikliklerin kontrol görevlilerine gida işletmecileri nezdinde tutarsızlık imajı yüklemesinin yanında kontrol görevlilerinin hizmet içi eğitimlerle bilgilendirilmeleri ihtiyacını da doğurmaktadır. Ayrıca, düzenlemelerde muğlak ifadelerin olması resmi kontrollerde öznel yaklaşımlara neden olabilmesi bakımından önemlidir. Kontrol görevlilerinin resmi kontroller ile ilgili başlıca sorunları yeterli sayıda denetim ekibinin/personelin olmaması $(\% 70,71)$, işletme yetkililerinin olumsuz davranışları $(\% 59,60)$ ve gereksiz tüketici şikâyetleri $(\% 54,55)$ olduğu tespit edilmiştir. İstanbul ilinde 110000 adetten fazla g1da işletmesi bulunduğu (Anonim, 2016) düşünüldüğünde, resmi kontrollerin nitelik ve nicelik bakımından istenen düzeyde olmasının yeterli sayıda personelin görevlendirilmesi ile sağlanabileceği önemsenmelidir. Gıda işletmelerinde resmi kontroller esnasında yaşanması muhtemel olumsuz durumların kontrol görevlilerinin güvenlikleri açısından önemi yanında sonraki kontrolleri de olumsuz etkileyebileceği göz önünde bulundurulmalıdır. Ayrıca, Müdürlüğün kendine ait binası olmaması $(\% 36,36)$ ve fiziki mekânın darlığ 1 (\%31,31) fiziki yapı ve ekipmanlarla ile ilgili en önemli sorunlar olarak belirlenirken, ücretlerin yetersizliği $(\% 59,60)$, trafik ve ikamet sorunlarının mesai saatlerini olumsuz etkilemesi $(\% 41,41)$ ve görev dağılımındaki adaletsizliklerin olduğu düşüncesi $(\% 39,39)$ iş ile ilgili diğer önemli sorunlardır.

Çizelge 5 Kontrol görevlilerinin sorunları*

\begin{tabular}{|c|c|c|}
\hline Gıda Mevzuatı İle İlgili Sorunlar & Frekans & $\%$ \\
\hline Mevzuatta çok sık değişiklik yapılması & 74 & 74,75 \\
\hline Anlaşılmasında güçlük yaşanması, yoruma açık olması & 70 & 70,71 \\
\hline Mevzuatlar arasında tutarsızlık olması & 35 & 35,35 \\
\hline İlgili kesimlerin ihtiyaçlarına yeterince cevap verememesi & 32 & 32,32 \\
\hline Mevzuatın çok fazla sayıda olması & 31 & 31,31 \\
\hline Gıda güvenliği ve güvenilirliğini sağlamada yetersiz olması & 20 & 20,20 \\
\hline Resmi Kontroller İle İlgili Sorunlar & Frekans & $\%$ \\
\hline Yeterli sayıda ekip/personel olmaması & 70 & 70,71 \\
\hline İşletme yetkililerinin olumsuz davranışları & 59 & 59,60 \\
\hline Gereksiz tüketici şikâyetleri & 54 & 54,55 \\
\hline Denetim sayısının fazlalı̆̆ & 49 & 49,50 \\
\hline Denetlenmesi gereken işletme sayısının fazlalığı & 46 & 46,46 \\
\hline Denetim sahasının geniş olması & 30 & 30,30 \\
\hline İl Kontrol Laboratuvarının uzak olması & 25 & 25,25 \\
\hline Şikâyet sayısının kontrolün niteliğini olumsuz etkilemesi & 22 & 22,22 \\
\hline Yasal işlem uygulamada zorluk yaşanması & 22 & 22,22 \\
\hline GGBS'nin bilgi akışını sağlamada yetersiz olması & 12 & 12,12 \\
\hline Fiziki Yapı ve Ekipmanlar İle İlgili Sorunlar & Frekans & $\%$ \\
\hline Müdürlüğün kendine ait binası olmaması & 36 & 36,36 \\
\hline Fiziki mekânın darlığı & 31 & 31,31 \\
\hline Denetim araç-gereçlerinin yetersizliği & 26 & 26,26 \\
\hline Yeterli sayıda denetim aracinın (otomobil) olmaması & 24 & 24,24 \\
\hline Bilgisayar, internet, fotokopi, faks vb. araç-gereçlerin yetersizliği & 14 & 14,14 \\
\hline İş İle İlgili Diğer Sorunlar & Frekans & $\%$ \\
\hline Ücretlerin yetersizliği & 59 & 59,60 \\
\hline Trafik ve ikamet sorunlarının mesai saatlerini olumsuz etkilemesi & 41 & 41,41 \\
\hline Görev dağılımında adaletsizlik & 39 & 39,39 \\
\hline Kontrol görevlileri arasında yaşanan uyumsuzluk & 21 & 21,21 \\
\hline Memur ve işçi personel arasındaki çatışmalar & 19 & 19,19 \\
\hline Kontrollerin yılllk izinleri olumsuz etkilemesi & 12 & 12,12 \\
\hline Yardımcı personelin ve desteğinin yetersizliği & 5 & 5,05 \\
\hline
\end{tabular}

* Birden çok cevap verildiği için toplam \%100’ü geçmektedir. 
Çizelge 6 Kontrol görevlilerinin resmi kontrolleri yeterli ve etkin bulma durumu ile sosyo-ekonomik özellikleri arasındaki ilişkiler

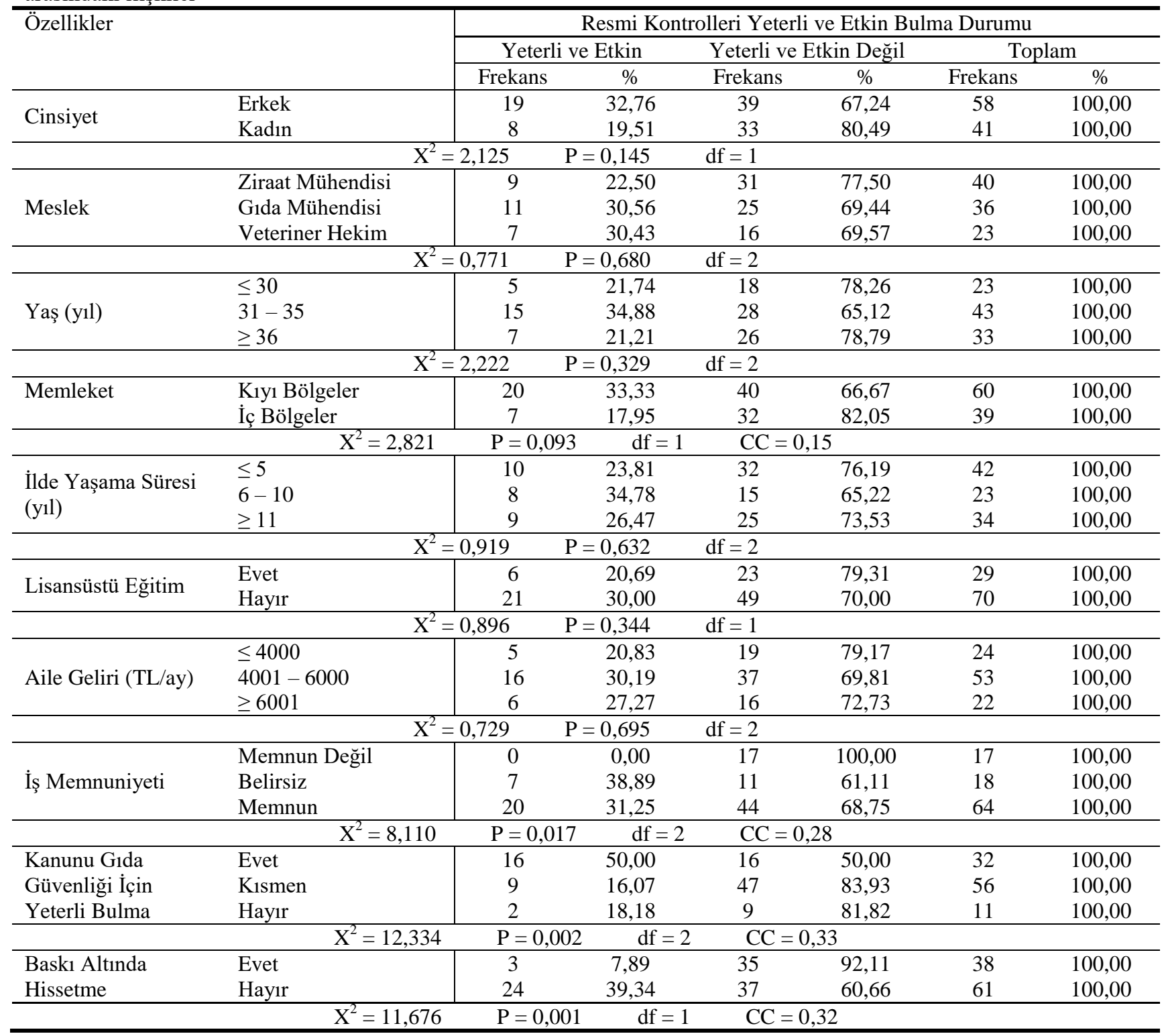

İlçe Müdürlüklerinin diğer kurum ve kuruluşlarla aynı binada hizmet vermesinin avantaj ve dezavantajları orta ve uzun vadede değerlendirilerek tercih yapılması yararlı olabilir. Diğer sorunların ise baskı unsuru konumundaki sendikalar aracılığıyla çözümü sağlanabilir. Eğitim eksikliği ve mesleki gelişim için zaman ayrılamaması, idare tarafından kontrol görevlisi olmanın dişında görevlerin de verilmesi, yillık izinlerin süresinin az olması, servis, öğle yemeği, kreş vb. imkânların olmaması, kurumda hiyerarşik kuralların yeterince bulunmaması ve uygulanmaması kontrol görevlilerinin karşılaştıkları diğer sorunlardır. Ayrıca, kontrol görevlilerinin 5996 sayılı kanun ile ilgili kamuoyunun yeterince bilgilendirilmesi, hizmet içi eğitimlerin artırılması, resmi kontrollerdeki güvenlik probleminin giderilmesi, personele performansa göre ücretlendirme yapılması, resmi kontrollerde nicelikten ziyade niteliğin önemsenmesi, tüketicilere Alo Gıda 174 şikâyet hattının kullanımı ile ilgili sorumluluk getirilmesi gibi beklentileri bulunmaktadir.
Kontrol Görevlilerinin Resmi Kontrolleri Yeterli ve Etkin Bulma Durumu ile Bazı Özellikleri Arasındaki İişkiler

Kontrol görevlilerinin resmi kontrolleri yeterli ve etkin bulma durumu ile bazı özellikleri arasındaki ilişkinin tespiti için yapılan Khi-kare testi sonuçları Çizelge 6'da verilmiştir. Çizelge incelendiğinde, memleketi kıyı bölgelerde olan kontrol görevlilerinin \%33,33'ünün resmi kontrolleri yeterli ve etkin bulmalarına karşın, memleketi iç bölgelerde olanların sadece \%17,95'i kontrolleri yeterli ve etkin bulmuştur. Kişilerin memleketleri ile kontrolleri yeterli ve etkin bulma durumu arasında $\mathrm{P}<0,10$ önem düzeyinde bir ilişki bulunmuş olup, bu ilişkiye ait bağımlılık katsayısı 0,15 olarak hesaplanmıştır. Resmi kontrollerin yeterli ve etkin bulunup bulunmama durumunu etkileyen diğer bir değişken kişilerin iş memnuniyetleridir. Yaptığ 1 işten memnun olan kontrol görevlilerinin \%31,25'inin resmi kontrolleri yeterli ve etkin bulduğu belirlenmiştir. Kişilerin iş memnuniyetleri ile kontrolleri yeterli ve etkin bulma durumu arasında bir ilişki $(\mathrm{P}<0,05)$ olup, bu 
ilişkinin bağımlılık katsayısı 0,28 'dir. Kontrol görevlilerinin 5996 sayılı kanunun g1da güvenliğini sağlamada yeterli bulma durumlarının resmi kontrolleri yeterli ve etkin bulmada etkili olabileceği düşünülmüş ve bir ilişkinin varlığı araştırılmıştır. 5996 sayılı kanunu gıda güvenliğini sağlamada yeterli bulduğunu söyleyen kişilerin \%50,00'sinin resmi kontrolleri yeterli ve etkin bulmasına karşın, kısmen yeterli bulanların \%16,07'sinin ve yetersiz bulanların ise \%18,18'inin kontrolleri yeterli ve etkin bulduğu saptanmıştır. Yapılan analiz de bu durumu doğrulamakta olup, 5996 sayılı kanunu gida güvenliğini sağlama konusunda yeterli bulma ile resmi kontrolleri yeterli ve etkin bulma durumu arasında $\mathrm{P}<0,05$ önem düzeyinde bir ilişki bulunduğu tespit edilmiştir. Bağımlılı katsayısı 0,33'tür ve güçlü bir ilişkinin olduğunu göstermektedir. Kontrol görevlilerinin gida işletmelerine yasal işlem uygularken baskı altında hissetmeleri ile resmi kontrolleri yeterli ve etkin bulma durumu arasında da bir ilişkinin $(\mathrm{P}<0,001)$ olduğu belirlenmiştir. Yasal işlem uygularken baskı altında hissetmediğini ifade eden kişiler $(\% 39,34)$, baskı altında hissettiğini söyleyenlere $(\% 7,89)$ göre resmi kontrolleri daha yüksek oranda yeterli ve etkin buldukları saptanmıştır. Bu ilişkinin bağımlılık katsayısı 0,32 olarak hesaplanmış olup, güçlü sayılabilecek bir ilişkiye işaret etmektedir. Ancak, kontrol görevlilerinin cinsiyet, meslek, yaş, ilde yaşama süresi, lisansüstü eğitim alma durumu ve aile geliri özellikleri ile resmi kontrolleri yeterli ve etkin bulma durumu arasında herhangi bir ilişki tespit edilememiştir.

\section{Sonuç}

Türkiye'de gıda güvenliğinde hızla genişleyen şehir alanlarının tarım alanlarını tehdit etmesi ve sanayileşme ile birlikte toprak ve içilebilir su kaynaklarının azalması ve kirletilmesi, tarımsal gübre ve ilaçların üreticiler tarafından bilinçsizce kullanılması, tarladan sofraya tüm gıda işletmelerinin sayısının fazlalığı ve yapısal eksiklikleri ile işletmeci ve çalışanların yeterli eğitime sahip olmaması, yapılan işin kişinin yeteneğine uygunluğu, yasal düzenlemelerin bilinmesi ve uygulanmasındaki zorluklar, kontrol hizmetlerindeki eksiklikler ve sosyo-ekonomik yapıdaki yetersizliklere paralel olarak toplumun riskli sayılabilecek gıda tüketim alışkanlıklarının etkili olduğu ifade edilmektedir. Türkiye'de gıda ve gıda ile temas eden madde ve malzemeleri üreten, depolayan, satışını ve dış ticaretini yapan tüm işletmelere onay ve kayıt verilmesi ile bu işletmelerin teknik ve hijyen özellikleri bakımından resmi kontrolleri 5996 sayılı Veteriner Hizmetleri, Bitki Sağlığ Gıda ve Yem Kanunu ile Gida, Tarım ve Hayvancılık Bakanlığı'nın yetki ve sorumluluğuna verilmiştir. $\mathrm{Bu}$ hizmetin tek bir kurum bünyesinde yürütülüyor olması yetki karmaşasını ortadan kaldırarak etkin bir şekilde gıda güvenliği risklerinin hızlı bir şekilde azaltılabilmesi bakımından önemli bir durumdur.

Bu çalışma, gıda güvenliği unsurlarından olan devletin yasal düzenlemelerine gida işletmelerinin uygunluğunun tespitinden sorumlu kontrol görevlilerinin ilk kez sosyoekonomik özelliklerini ortaya koyması ve sorunlarını belirlemesi bakımından önem taşımaktadır. İstanbul ilindeki kontrol görevlilerini kapsayan bu çalışmada, kişilerin çoğunlukla erkek, genç sayılabilecek yaşta, üçte biri lisansüstü öğrenimli, hayatlarının üçte birine yakınını bu şehirde geçirmiş ve evli oldukları belirlenmiş olup, çekirdek aile yapısının hâkim olduğu, çoğunlukla eşlerin çalıştığı ve sınırlı düzeyde tasarrufun yapıldığı ailelerinden oluştukları saptanmıştır. Kişilerin çoğunluğunun son yasal düzenleme ile göreve başladığ ve kontrol görevlisi olarak çalıştığ 1 , çoğunluğunun HACCP temel eğitimi aldığ 1 ve yaklaşık üçte ikisinin yaptığ 1 işten memnun olduğu tespit edilmiştir. Kişilerin yarısına yakınının önceki kanunu incelediği ve üçte birinden fazlasının önceki kanunda da görevli olduğu, güncel kanunu g1da güvenliğini sağlama konusunda önceki kanuna göre yeterli buldukları ve güncel kanunu tercih ettikleri, yapilan resmi kontrolleri yeterli ve etkin bulanların azınlıkta olduğu, üçte birinden fazlasının yasal işlem uygularken çeşitli unsurlar nedeniyle kendilerini baskı altında hissettiği ve güncel kanunun özellikle yetki paylaşımı, hizmet alımı ve yetki devri hükümlerine katılmadıkları saptanmıştır. Kontrol görevlilerinin mevzuat, resmi kontroller, fiziki yapı ve ekipmanlar ile diğer birçok soruna maruz kaldıkları bulunurken, beklenti ve isteklerinin karşılanabilir nitelikte olduğu görülmektedir. Ayrıca, Khi-kare testi sonucunda memleket, iş memnuniyeti, güncel kanunu gıda güvenliğini sağlamada yeterli bulma ve yasal işlem uygularken baskı altında hissetme değişkenlerinin resmi kontrolleri yeterli ve etkin bulma durumu bakımından farklılık göstermektedir. Öncelikle yapılan bu çalışmanın zaman içerisinde oluşabilecek ihtiyaçlara göre yeni çalışmalarla desteklenmesi önemlidir. Gıda ürünleri için üretimden tüketime tüm aşamalarında işletme içi tedbirlerin alınması ile gerekli kontrollerin yapılmasının yanında, yeterli ve etkin bir resmi kontrol sisteminin bulunması gıda güvenliğinin sağlanması ve ekonomik kayıpların önlenmesine yardımcı olabilir. $\mathrm{Bu}$ nedenle öncelikle kontrol görevlilerinin yapılan resmi kontrolleri gıda işletmelerinin mevzuata ilişkin eğitim ihtiyaçlarının karşılanması aşamasında rehberlik hizmeti olarak görmeleri önemlidir. Böylelikle gıda işletmelerinin her aşamada teknik ve hijyen kurallarına uygunluğu ve ürünlerin sağlıklı ve kaliteli olması yani gıdaların topluma daha sağlıklı biçimde sunulması sağlanabilecektir. Ayrıca, gıda işletmelerine uygulanan idari yaptırımların caydırıcı olması yanında anlaşmazlıklar ve hukuka aykırı durumlar için gıda mahkemelerinin oluşturulmasının kısa vadede gündeme alınması önemsenmelidir. Sonuç olarak, resmi kontrollerden beklenen başarının gida kontrol mekanizmasının belirli aralıklarla gözden geçirilmesi, tespiti yapılan çeşitli sorunların ortadan kaldırılması, yeterli mesleki eğitimi alarak uzmanlaşmış bir ekip için etkin ve koordineli bir çalışma ortamının oluşturulması ile sağlanabileceği göz önünde bulundurulmalıdır. Bu sayede gıda güvenliğinin sağlanması konusunda değişim ve gelişimler meydana getirilebilecektir.

\section{Kaynaklar}

Akpınar Ş. 2012. Gıda İşletmecisinin Sorumlulukları. Ordu'da Gıda Güvenliği, Sayı: 17, Ordu.

Alemdar T. 2008. Küresel Değer Zincirleri İçerisinde Türk Gıda Sektörünün Konumu. VIII. Ulusal Tarım Ekonomisi Kongresi, 25-27 Haziran 2008, 35-45, Bursa.

Anonim. 2012a. Çiftlikten Sofraya Gıda Güvenilirliği. Ordu'da Gıda Güvenliği, Sayı: 17, Ordu. 
Anonim. 2012b. Gıda Zehirlenmelerinde Etken Faktörler. Ordu'da Gıda Güvenliği, Sayı: 17, Ordu.

Anonim. 2015. Gıda, Tarım ve Hayvancılık Bakanlı̆̆ı, Gıda Güvenliği Bilgi Sistemi (GGBS). (https://ggbs.tarim.gov.tr/) [Erişim: 28.08.2015].

Anonim. 2016. Gıda, Tarım ve Hayvancılık Bakanlığı, Gıda Güvenliği Bilgi Sistemi (GGBS). (https://ggbs.tarim.gov.tr/) [Erişim: 01.02.2016].

Balçık Mısır G, 2008. HACCP, Gıda Güvenliği ve Risk Yönetim Sistemi. Su Ürünleri Merkez Araştırma Enstitüsü (SUMAE) Yunus Araştırma Bülteni, 8(3): 8-10.

Baş D, Deniz E. 2015. Gida Güvenliği ve Kalite Kontrolünde $\begin{array}{lllll}\text { Biyosensörler. Gida (2015) } 40 \quad \text { (4):225-232 } & \end{array}$ doi:10.15237/gida.GD14057).

Bayat A. 2015. Gıda Güvenliği Kavramı ve Türkiye'de Durum. Çukurova Üniversitesi Gıda Çalışanları, Hijyen Eğitimi Rehberi, Sayfa:1-5, Adana.

Bayrak A, İlbeği I. 1997. Gıda Güvenliğine Bir Bakış. Standart Dergisi, 3(36) 423-426.

Çağlarırmak N. 2008. Endüstrileşmenin Gıda Üretimleri ve Gıda güvenliğine Etkileri. Türkiye 10. Gida Kongresi, Erzurum.

Çiçek A, Erkan O. 1996. Tarım Ekonomisinde Araştırma ve Örnekleme Yöntemleri. GOÜ Ziraat Fakültesi Yayınları No:12, Ders Notları Serisi No:6, Tokat.

Çopur ÖU, Yonak S, Şenkoyuncu A. 2010. Gıda Güvenliği ve Denetim Sistemi. Ziraat Mühendisliği VII. Teknik Kongresi. 11-15 Ocak 2010. Ankara Bildiriler Kitab1-2 1127-1137.

Düzgüneş O, Kesici T, Gürbüz F. 1983. İstatistik Metodları I. Ankara Üniversitesi Ziraat Fakültesi Yayınları: 861, Ders Kitabı: 229, Ankara.

Erbelet E. 2014. Gıda Güvenliğinin Türk Tarım Politikalarındaki Yeri ve Türk Tarımına Etkisi (Yüksek Lisans Tezi). İstanbul Üniversitesi Sosyal Bilimler Enstitüsü İktisat Bilim Dalı İktisat Politikası Anabilim Dalı, İstanbul.

Erden C. 2012. Türkiye'de Gıda Güvenliğinde Karşılaşılan Sorunlar ve Gıda Güvenliğinin Benimsenmesinde Eğitim Yöntemlerinin Uygulanabilirliği (Yüksek Lisans Tezi). Namık Kemal Üniversitesi Fen Bilimleri Enstitüsü Tarım Ekonomisi Anabilim Dalı, Tekirdağ.

Erkan N, Üçok Alakavuk D, Tosun YŞ. 2008. Gıda Sanayinde Kullanılan Kalite Güvence Sistemleri. Journal of FisheriesSciences.com, ISSN 1307-234X (DOI:10.3153/jfscom.200809, 2(1):88-89.

Erkmen O. 2010. Gıda Kaynaklı Tehlikeler ve Güvenli Gıda Üretimi. Çocuk Sağlığ 1 ve Hastalıkları Dergisi, 53:220-235.

Giray H, Akın A, Dölekoğlu C, Gün S. 2006. Gıda Güvenliği ve AB Uyum Sürecinde Türkiye'de Yaşanan Gelişmeler. Türkiye VII. Tarım Ekonomisi Kongresi, Antalya 2006, s.197.

Giray H, Soysal A. 2007. Türkiye'de G1da Güvenliği ve Mevzuatı. TSK Koruyucu Hekimlik Bülteni, 6 (6): 485-490.

Gujarati DN. 1995. Basic Econometrics. $3^{\text {rd }}$ Edition, McGraw Hill, Inc., New York.
Güneș E, Ünsal F. 2006. Türkiye'de Gıda Sektörünün Ekonomik Yapısı ve Avrupa Birliğine Uyumu. Türkiye 9. Gıda Kongresi, Sayfa:119-122, Bolu.

Halaç E. 2002. Gıda Kalitesi ve Gıda Mevzuatı İle İlgili Temel Kavramlar Işı̆̆ında Türk ve AB Gıda Mevzuatının Karşılaştırılması. Akdeniz İ.İ.B.F. Dergisi (4), 107-131.

İba S. 2013. Uluslar arası Güvenlik Anlayışında Gıda Güvenliği Sorunsalı: Avrupa Birliği-Türkiye Karşılaştırmalı Analizi (Doktora Tezi). İstanbul Üniversitesi Sosyal Bilimler Enstitüsü Avrupa Birliği Anabilim Dalı, İstanbul.

Kılıç D. 2008. Tüketicilerin Gıda Güvenliği İle İlgili Bilgi, Tutum ve Davranışları (Yüksek Lisans Tezi). Gazi Üniversitesi Eğitim Bilimleri Enstitüsü Aile Ekonomisi ve Beslenme Eğitimi Bilim Dalı, Ankara.

Mirer TW. 1995. Economic Statistics and Econometrics. $3^{\text {rd }}$ Edition, Prentice Hall, Inc., New Jersey.

Okur Z. 2015. Gida Güvenliği Kavramı ve Türkiye'de Durum. Çukurova Üniversitesi Gıda Çalışanları, Hijyen Eğitimi Rehberi, Sayfa:6-11, Adana.

Oral E. 2009. Tarım Ürünlerinin Gıda Güvenliği Bilgi Sistemleri İle İzlenebilirliği (Yüksek Lisans Tezi). Hacettepe Üniversitesi Gıda Mühendisliği Anabilim Dalı, Ankara.

Öksüztepe G, Beyazgül P. 2015. Akıllı Ambalajlama Sistemleri ve Gıda Güvenliği. Fırat Üniversitesi, Sağlı Bilimleri Veterinerlik Dergisi, 29 (1): 67-74.

Ören MN, Alemdar T, Bahadır B. 2008. Türkiye'de Tarım Politikalarının Gıda Güvencesi Üzerindeki Etkileri. VIII. Ulusal Tarım Ekonomisi Kongresi, 25-27 Haziran 2008, 4657, Bursa.

Özbek FŞ, Fidan H. 2009. Türkiye ve Avrupa Birliği'nde Gıda Standartları. Selçuk Üniversitesi Ziraat Fakültesi Selçuk Tarım ve Gıda Bilimleri Dergisi, 24 (1): 92-99.

Serpen A. 2007. AB Sürecinde Türkiye'de Gıda Güvenliğinin Dünü, Bugünü ve Yaşanmakta Olan Kargaşanın Değerlendirilmesi. Hayvancilık Performans Dergisi, Say1:108, İstanbul.

Sharafkhani R, Dastgiri S, Gharaaghaji R, Ghavamzadeh S, Didarloo A. 2010. The Role of Household Structure on the Prevalence of Food Insecurity. European Journal of General Medicine, 7 (4): 385-388.

Topuzoğlu A, Hıdıroğlu S, Ay P, Önsüz F, İkiışık H. 2007. Tüketicilerin Gıda Ürünleri İle İlgili Bilgi Düzeyleri ve Sağlık Risklerine Karşı Tutumları. TSK Koruyucu Hekimlik Bülteni, 6 (4):253-258.

Yılmaz E, Oraman Y, İnan İH. 2009. Gıda Ürünlerine İlişkin Tüketici Davranışı Dinamiklerinin Belirlenmesi: "Trakya Örneği”. Tekirdağ Ziraat Fakültesi Dergisi, 6(1): 1-10.

Yorulmaz F. 2002. 1988-1998 Yılları Arası Edirne Bölge Hıfzıssıhha Müdürlüğü Gıda Güvenliği İnceleme Sonuçlarının Değerlendirilmesi. Türk Hijyen ve Deneysel Biyoloji Dergisi, 59 (1,2,3):51-56.

Yörük GN, Güner A. 2014. Gida Güvenliğinin Tarihsel Gelişimi. 2. Ulusal Laboratuvar Akreditasyonu ve Güvenliği Sempozyumu, İstanbul, s.102-103. 